[DOI: 10.24214/jecet.A.7.3.37282]

Journal of Enviranmental Science, Computer Science and Engineering \& Technology

An International Peer Review E-3 Journal of Sciences and Technology

Available online at www.jecet.org

Section A: Environmental Science

Research Article

\title{
Infrastructural Development and Improving Livelihoods of Rural People in Nepal: A Case Study of Kanchanpur District Nepal
}

\author{
Ishwor Datt Awasthi \\ PhD scholar,Tribhuvan University, Kathmandu, Nepal
}

Received: 27 April 2018; Revised: 28 May 2018; Accepted: 08 June 2018

\begin{abstract}
Infrastructure is the vital prerequisite and utmost essential element of physical change and social development. It is a backbone of economic development as well as, is a catalytic component for progress and welfare in the lives of rural poor residents. In this connection, the infrastructural development play a crucial role in reducing poverty and lay down the foundation stone intended for rural development and economic acceleration in remote areas. In every society of the developing and underdeveloped third world, there is need of proper infrastructural development, in this study the relationship between availability of infrastructures and quality of living along with means of subsistence is analyzed in concrete ways. This study summarizes that abundance number of basic infrastructures like drinking water, transportation, irrigation, information and communication, health services and educational facilities has the great influence on the better living conditions and livelihoods of poor people. In essence, the presence of indispensable rural infrastructures has significant impact on the livelihoods of rural people in Nepal.
\end{abstract}

Key words: Infrastructure, Rural Development, Livelihoods, Poverty.

\section{INTRODUCTION}

Infrastructure establishment contributes to inclusive rural development, it provides easy access to markets, and basic services that people need. Infrastructure also increases employment opportunities 
and transform agricultural occupation to the off-farm activities, increases the purchasing power, consumption pattern, and saving capacity of the people resulting the reduction of poverty.

Carney ${ }^{1}$ points out that about $70 \%$ of the world's poor live in rural areas. Though urban poverty is rising, the correlation between poverty and remoteness from urban centres is strong in most countries and it is expected to remain so until at least the second decade of the next century. Clearly therefore the International Development Target of halving the number of people living in extreme poverty by 2015 will be achievable if the problem of rural poverty is confronted head on. Rural people are not only isolated from economic opportunities. They also tend to have less access to social services such as health, sanitation and education; for example, it is estimated that around 1 billion rural households in developing countries lack access to safe water supplies. Moreover, knowledge of rights and information about the way governments function is notably lacking in rural areas. in rural areas a) the poor are small farmers and b) agriculture acts as the engine of growth, investing in agriculture has long been seen as a means of simultaneously addressing both growth and equity issues.

Molden et $a .^{2}$ gives the detail picture of the world scenario of rural population that in 1995 , the world's rural population was estimated to be 55 percent of its total population. While this represents a decline of 10 percent from the proportion of rural population in 1965 (estimated to be 65\%), in absolute terms, the rural population has increased from 2.1 billion in 1965 to 3.1 billion in 1995 . The world's rural population is projected to grow at a slower rate over the coming decades, due to rapid urbanization and industrialization, particularly in developing countries. The total rural population over the next 30 years is projected to increase only by 6 percent, from 3.1 billion in 1995 to 3.3 billion in 2025 .

Approximately half of the population of world is living in rural areas. According to the data released by the United Nations Department Of Economic And Social Affairs Population Division out of total world population 49.9 percentage of people live in rural areas of different countries, the world's least developed countries has the highest percentage (71.3) of rural population followed by developing countries $(53.4 \%)$, developed countries has only small portion $(25.1 \%)$ of population. The population of the developing world is still more rural than urban, some 3.1 billion people or 55 percent of the total population, live in the rural areas ${ }^{3}$.

Shisodia ${ }^{4}$ points out that rural development is a process aimed at improving the well being of the

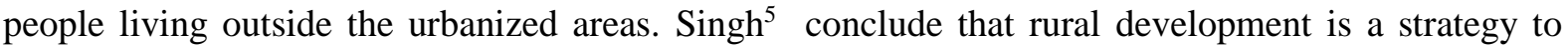
enable a specific group of people, poor rural women and men to gain for themselves and their children more what they want and need. It improves helping the poorest among those who seek a livelihood in the rural areas to demand and control more of the benefits of rural development.

A well formulated plan to develop rural infrastructure focusing on agriculture, trade and tourism, will yield, huge returns and contribute enormously to the overall development of the region. The infrastructure is the backbone of an economy and the role of infrastructure in improving quality of life is well acknowledged. Better access to social and economic infrastructure not only enhances production and productivity in agriculture but also leads to a reduction in wastage ${ }^{6}$.

Oraboune $^{7}$ argue that importance of infrastructure as, improvement of rural road seems to be a clear means by which large number of people especially rural people might acquire the opportunity to participate in the market economy and thereby raise themselves out of poverty. According to him there is a close link between village connecting roads and poverty reduction through increase in income opportunities to rural people. He further emphasize that rural connecting road provides market access opportunities to rural farmers and they can develop market linkage with other stake holders in 
the economy. This helps the farmers diversify their income sources as they have linked with more variety of functional livelihood value chain system.

Pramod and $\mathrm{Ballal}^{8}$ agree that close involvement of the people in the planning and implementation of the basic needs and anti poverty programmes are essential for success. Finally they recognize that transfer of technology, education and training are very crucial to increase the sustainability of the development programmes.

Awareness of livelihoods and diversity can lead to the better formulated rural poverty reduction policies than those based conventionally on sectors and sub sectors ${ }^{9}$. The adequacy of infrastructure helps to determine the states success or failure in agriculture in terms of level of production and diversifying the sector. He also explains that many people, especially the rural poor, and areas do not have access to even minimal infrastructure services, he adds further if a nation aspires to attain maturity in economic growth; it must give a big push to upliftment of the network of physical infrastructure like energy, transport, etc ${ }^{10}$.

Fan and Zhang ${ }^{11}$ found that about more than 70 percent of population in rural areas depend upon land for their livelihood; people in rural areas prefer to invest their surplus earnings in purchasing land.

Improvements in living standards of rural people that we act only in one field, say education which will automatically create enthusiasm and faith to act in all other fields, providing a cascading effect to all side emancipation of rural people ${ }^{12}$. Donnges et al. ${ }^{13}$ examine that access is only improved if road investments result in positive changes in transport. Benefits may then arise from improved access to markets and jobs. They describe again other benefits may result from improved transport services, reduced travel and transport costs and employment created during construction and maintenance. $\mathrm{Li}$ and $\mathrm{Liu}^{14}$ found in their study that rural infrastructure not only provides essential agricultural production conditions such as roads, telecommunications, powers and irrigation systems, but also provides education and medical services related to enhancing the quality of life of rural labors. The importance of rural infrastructure has been a crucial to promoting economic growth and development. He also suggested that the development of rural infrastructure must be seen as an integral part of the entire economic growth and development ${ }^{15}$.

Gunatilaka ${ }^{16}$ identifies the poverty reduction measures that rural poverty needs to incorporate policies to develop both production-oriented and welfare-oriented infrastructure, in order to improve poor people's productive capacity and quality of life. Providing services such as irrigation, power and transport in rural areas would open up new opportunities for diversifying incomes and employment in backward areas.

Chandra ${ }^{17}$ points out that development of agricultural and rural areas is both a big challenge and a lifetime opportunity before the political masters, planners, bureaucrats and the people at large o prove that they are fully and truly connected to transferring villages into a very dynamic and vibrant sociocultural and economic entity. Rural development planning the schemes are 'supply' based and not 'demand' based to achieve acceptability and active participation of the targeted beneficiaries. It is needless to emphasize that the schemes and projects should be 'demand' based ${ }^{18}$.

Douglas et al. ${ }^{19}$ describe the importance of rural infrastructure as it plays a significant role in agricultural development, the availability of electricity, roads; markets and credit are all part of the rural environment in which farmers make decisions about cropping practices. First, access to infrastructure has an impact on farming practices, second, the adoption of new farming practices, including hybrid seeds and fertilizers in turn have an impact on agricultural yields. 
Naranyanamoorthy et al. ${ }^{20}$ in their empirical survey research of 256 districts in India found that the district having value of agricultural output above the average are better placed in terms of rural infrastructure development (irrigation, road, literacy, school facility, rural electrification, fertilizers) than other districts. This implies significant scope for increasing agricultural output by improving rural infrastructure such as irrigation, roads, education, and electrification etc.

Cheema $^{21}$ highlights that each country in Asia several policies, programmes and projects have been introduced to increase agricultural productivity; raise income and living standards of rural people, provide employment opportunities; facilitate the participation of the people in local decision-making; and increase access of the rural poor to government facilities and programmes.

Donnges et al. ${ }^{22}$ in their Integrated Rural Accessibility Planning in Nepal Guideline revel that a new Local Infrastructure Development Policy was approved in late 2004 in Nepal. This policy covers infrastructure for local transportation, irrigation and river control, small hydro power and alternate energy, drinking water, sewerage and sanitation, housing, building and urban development, management of solid waste and social infrastructure including government offices, health, education etc.). The policy aims at increasing the participation of the local people in physical and social infrastructure development to enhance the social services, economic opportunities and mobilization of local resources.

Dev et $a l .{ }^{23}$ in their study of Community forest in Nepal suggest poverty reducing manners and sustainable income for better livelihoods as community forestry can open up new livelihood opportunities for Forest Users Group members, for example the cultivation of the spice cardamom or the tapping of resin in the forest. In such cases, a critical issue is the distribution of these benefits amongst different groups in the FUG. Thus, the sustainable level of 'income' can be improved, with fewer concerns about gathered forest products and/or more secure livestock production.

\section{STUDY AREA}

Nepal lies in the transitional region between Indo Malayan and Palearctic bio geographical realms. Its unique geographical position and the altitudinal and climatic variations have resulted in nine bio climatic zones, from tropical to naval within a vertical span of less than $200 \mathrm{~km}$. Most of Nepali territory (86\%) comprises of the hills and mountains ${ }^{24}$.

Nepal is of almost quadrilateral shape, approximately 800 kilometers long and 200 kilometers wide. It lies between latitudes $26^{\circ}$ and $31^{\circ} \mathrm{N}$, and longitudes $80^{\circ}$ and $89^{\circ} \mathrm{E}$. Naturally, Nepal is divided into three geographical areas: Mountain, Hill and Terai(plain belt). These ecological belts extend east to west and are vertically crossed by Nepal's major, north to south flowing river systems.

The southern flat plains or Terai neighboring India are part of the northern edge of the Indo Gangetic plane. This is the main arable land of Nepal and irrigated by of three main Himalayan rivers. This region has subtropical to tropical climate zones. The northern hilly and mountainous part is linked with Tibetan Pleatu of Chinese autonomous region. Nepal officially the Federal Democratic Republic of Nepal, has 7 number of newly devised provinces is a landlocked located in South Asia, with an area of 147,181 square kilometers $(56,827 \mathrm{sq} \mathrm{mi})$ and a population of about 27 million ${ }^{25}$. Nepal is the world's 93rd large country by area and the 41 st most populous nation ${ }^{26}$.

Nepal is very poor country in the world, Nepal's 10th Five Year Plan set out the overall national development objective of reducing poverty from $31 \%$ to less than $21 \%$ by the end of 2015 , but this goal is not achieved so far yet. The Millennium Development Goal progress report currently estimates Nepal's poverty rate ${ }^{27}$ to be at $25.4 \%$. This figure however is contested by another report ${ }^{28}$ which 
states that Nepal's current poverty rate is at $65 \%$ which is significantly higher than what the former report states. This also goes to further prove that Nepal still has quite a few challenges in overcoming poverty, and therefore the poor and inadequate infrastructure issues are main cause of misery and distress of Nepali people, thus special focus should be to poverty alleviation from rural areas is seen tough and challenging due to lack of high amount of investment in rural infrastructure development projects since more than $85 \%$ of Nepal's population is still living in rural areas, dependent on subsistence farming with the surrounding natural resources as their only means for a livelihood.

The above scenario tells us that infrastructure gaps present a significant challenge for Nepal's short and longer term development goals. Therefore Nepal has to invest between sufficient budget well over a billion dollar annually, to adequately develop its infrastructure especially in the rural sectors. The employment and non farm occupational diversification has been increased in the recent decades due to the implementation of infrastructural developments works in Nepal.

According to Nepal Living Standard Survey carried out by CBS ${ }^{29}$ the average household income grew by more than 363 percent between 1995/96 and 2010/11 (NRs. 43,732 versus NRs.202, 374). During the same period, mean per capita income increased from Rs. 7,690 to Rs. 41,659 (an increase by 442 percent).

Nepal Multidimensional Poverty Index ${ }^{30}$, shows that $28.6 \%$ of Nepal's population is multidimensional poor. Naturally, the rural- urban divide is evident with $7 \%$ of urban population and $33 \%$ of rural population being multidimensionally poor. Study find the unique feature from the newly formed seven provinces that provinces 6 and 2 have the highest rate of multidimensional poverty, with second person being multidimensionally poor $(50 \%)$ followed by provinces 5 and 7 (approximately 30\%). Province 3 has the lowest (12.24\%) level of multidimensional poverty. provinces 4 and 1are ranked $2^{\text {nd }}$ and $3^{\text {rd }}$ positions in terms of their low poverty level with 14.19 and 19.67 percent of MPI respectively. According to the study it is found that Nepal halved its MPI 2006-2014. The incidence of multidimensional poverty has gone down from 59\% in 2006 to 39\% in 2011 and 29\% in 2014.

Major investments in social infrastructure like health, education and sanitation and Physical infrastructure like transportation, communication, electricity, drinking water, market, and finances will be necessary to lift poorest of the poor out of multidimensional poverty.

\section{METHODS AND MATERIALS}

This article is based on both primary and secondary data. The research is mainly based on quantitative data than qualitative; the quantitative data are collected adopting non-probability sampling technique with the help of self administered interview schedule that consists of questions of different types of scale. The interview schedules the filled up by field visit and personal interview method are then collected and codited, edited and finally the entry of data is taken place into SPSS software package is made thoroughly. In analyzing, statistical description, tabulation, simple percentage, average and testing hypothesis were made by using this SPSS software computer programme.

There are 7 blocks or wards in with 3979 households $(\mathrm{HH})$. The total numbers of Households in the study area is taken as the universe of this study population. Out of 3979 households the $120 \mathrm{HHs}$ were selected using Area and Simple Random Sampling statistical technique. For the interview criteria, to select the respondents from 120 sample households an individual aged between (20-60) years is requested to tap or sat for the interview, so as each Household $(\mathrm{HH})$ is considered as the sampling unit 
of the study. The information obtained from this study sample is the primary source of information. Based on this primary source of data, tabulation and findings, summary and conclusions are drawn.

This article also somewhat depends on secondary source of data. Some governmental, nongovernmental sector and international publications and reports related to study and area and topic are also taken as the secondary sources of data. The Jhalari Village, is a grass root level basic and small local administrative unit of Kanchanpur district in Nepal. Researcher selected the small administrative unit because of familiarity and closeness to the scio-economic characteristics of the study area. The study area is a rural locale is fulfilled with urban features, having basic infrastructural facilities and economic activities. In addition, the study area lies across the Mahindra National Highway roughly 27 kilometer far from the Nepal-India border. Just about, 15 years before there were lack of all the basic physical facilities like, rural roads, information and communication, electricity, drinking water, sanitation, health services and educational institutions. In the recent years, the Jhalari Village Development Committee (VDC) leaped ahead and numerous socio-economic activities and livelihoods figures are improving dramatically, so researcher selected this place as study area.

The two non-probability sampling techniques used for selection a study sample, first the Proportional Sampling Method is used to determine the exact proportion of sample population from each ward/block, subsequently to identify the particular households for interviewing and collecting information Simple Random Sampling Technique is used in this research work. To make the study participatory females are also given priority, approximately half (45\%) female respondents were then randomly sampled again to assign the gender assurance for the interview of this research work. Well structured questionnaires are the main tools of data collection, were used for studying various aspects of economic, social, and infrastructural relationships and impacts of the study area.

\section{RESULTS}

After the inception of rural infrastructural development programme the changes are witnessed in the lifestyle of the people of the study area. Respondents seen run businesses, got trainings for livelihood protection e.g. poultry farming, vegetable farming, craft training, fish farming etc. These programmes brought the fruitful results for the upliftment of Scheduled Caste and Scheduled Tribe community people. Jhalari Village Development Committee is in the crossroads between rural and urban features. There is accessible National Highway, district road networks and rural agricultural road networks, but most part of the roads are under construction and in the phase of advancement. There is well positioned infrastructure of information of communication, including latest $3 \mathrm{G}$ internet technology.

There are many of primary secondary and higher schools, nonetheless lack of technical colleges. The almost all the houses of Jhalari are under the grid connection of national electricity line. The drinking water supply to some extent is the problem of this area. Tube wells are the main source of drinking water some sources are polluted with arsenic content. Sanitation is within contentment condition, there are community forests, which provide the firewood, grass, and timber to the respondents of the study area. The land is agricultural, is very fertile and productive. There is a small market in Jhalari VDC, is the main commercial and trade centre of the area. These all infrastructures are main basics of the transformations on the livelihoods of the rural respondents of the Jhalari VDC. The following table entails further information regarding relationship between infrastructural development and improving livelihoods. 
Table 1: Association between Total Income of Family and Educational Status of Respondents

\begin{tabular}{|c|c|c|c|c|c|c|}
\hline \multirow{2}{*}{$\begin{array}{l}\text { Income } \\
\text { Level Rs. }\end{array}$} & \multicolumn{5}{|c|}{ Educational Status } & \multirow[t]{2}{*}{ Total } \\
\hline & Illiterate & Primary & Secondary & $\begin{array}{l}\text { Senior } \\
\text { Secondary }\end{array}$ & $\begin{array}{l}\text { Graduate and } \\
\text { Above }\end{array}$ & \\
\hline$<20000$ & 10 & 7 & 2 & 1 & 1 & 21 \\
\hline $21000-100000$ & 8 & 43 & 16 & 12 & 4 & 74 \\
\hline 100000 above & 2 & 1 & 5 & 6 & 2 & 25 \\
\hline Total & 20 & 51 & 23 & 19 & 7 & 12 \\
\hline \multicolumn{6}{|c|}{ Grand Total } & 120 \\
\hline \multicolumn{3}{|c|}{ Chi-Square Tests } & Value & df & \multicolumn{2}{|c|}{ Asymp. Sig. (2-sided) } \\
\hline \multicolumn{3}{|c|}{ Pearson Chi-Square } & $19.591^{\mathrm{a}}$ & 8 & \multicolumn{2}{|c|}{0.012} \\
\hline \multicolumn{3}{|c|}{ Likelihood Ratio } & 16.717 & 8 & \multicolumn{2}{|c|}{0.033} \\
\hline \multicolumn{3}{|c|}{ Linear-by-Linear Association } & 8.323 & 1 & \multicolumn{2}{|c|}{0.004} \\
\hline \multicolumn{3}{|c|}{ No. of Valid Cases } & 120 & & \multicolumn{2}{|l|}{ acted count is 123} \\
\hline
\end{tabular}

\section{Source: Calculated from field Survey}

\section{Description}

$\mathrm{H}_{0}$ : There is no association between educational status and income level of households of the respondents.

$\mathrm{H}_{\mathrm{a}}$ : There is association between educational status and income level of households of respondents. above table shows the cross tabulation and calculated value of Chi-Square is 19.591. The Tabulated value of chi-Square for a 0.05 probability level with 20 degree of freedom is 31.410

Result/ Decision:The computed value of $\chi^{2} 19.591$ is greater than the tabulated value of $\chi^{2}$ (31.410) at 0.05 significant level with a df of 8 , hence rejected the null hypothesis $\left(\mathrm{H}_{0}\right)$ and accepted alternative hypothesis $\left(\mathrm{H}_{\mathrm{a}}\right)$. Therefore the result of the hypothesis is there is association between educational status and income level of respondents of the study area.

Table 2:Association between Cell Phone Accessibility and Income Level of espondents

\begin{tabular}{|c|c|c|c|}
\hline \multirow{2}{*}{$\begin{array}{l}\text { Total Income of } \\
\text { Family(Rs) }\end{array}$} & \multicolumn{2}{|c|}{ Mobile Phone Accessibility of People } & \multirow[t]{2}{*}{ Total } \\
\hline & Access & Out of Reach & \\
\hline$<210000$ & 17 & 4 & 21 \\
\hline $21000-100000$ & 73 & 1 & 74 \\
\hline 100000 above & 24 & 1 & 25 \\
\hline Total & 114 & 6 & 120 \\
\hline Chi-Square Tests & Value & df & $\begin{array}{l}\text { Asymp. Sig. } \\
\text { (2-sided) }\end{array}$ \\
\hline Pearson Chi-Square & $10.851^{\mathrm{a}}$ & 2 & 0.004 \\
\hline Likelihood Ratio & 8.202 & 2 & 0.017 \\
\hline $\begin{array}{l}\text { Linear-by-Linear } \\
\text { Association }\end{array}$ & 4.661 & 1 & 0.031 \\
\hline No. of Valid Cases & 120 & & \\
\hline
\end{tabular}

Source: Calculated 


\section{Description}

$\mathrm{H}_{0}$ : There is no association between access to ICT and income level of households of in the study area.

$\mathrm{H}_{\mathrm{a}}$ : There is association between access to ICT and income level of households in the study area.

The above table shows the cross tabulation and calculated value of Chi-Square is 10.851. The Tabulated value of chi-Square for at 0.05 probability level with 5 degree of freedom is 11.071

Result/ Decision:The computed value of $\chi^{2} 10.851$ is greater than the tabulated value of $\chi^{2}$ (11.071) at 0.05 significant level with a df of 5 , hence rejected the null hypothesis $\left(\mathrm{H}_{0}\right)$, and accepted alternative hypothesis $\left(\mathrm{H}_{\mathrm{a}}\right)$. Therefore the result of the hypothesis is there is association between access to ICT and income level of respondents of the study area. Therefore it is obvious that the hypothesis formulated in this research article is tested and proves the intricate positive relationship between the availability of basic infrastructures and improvements in the means of earnings, livelihoods and living standards of people of rural area.

Table 3:Test for Equality of Mean Income of Sample Households

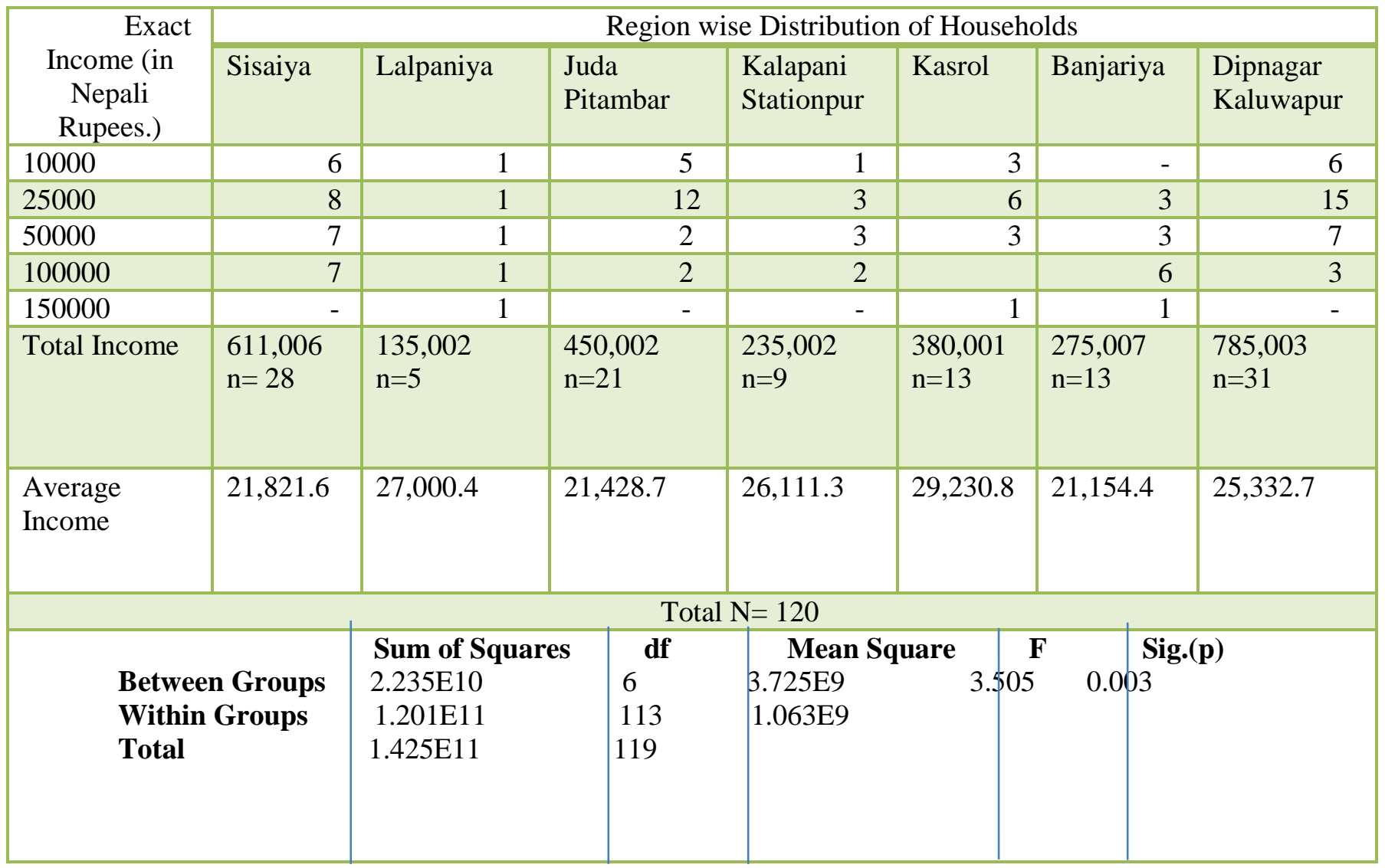

\section{Source: Computed}

From the above table it is observed that the computed $\mathrm{F}$ statistic value is 3.505 with a corresponding significant value $\mathrm{p}=0.003$. Since the $\mathrm{p}$ value is smaller than 0.05 , the null hypothesis is getting rejected, therefore it can be concluded that the average income of the households in different villages differ significantly 


\section{CONCLUSIONS}

This study constructed, depending on secondary data published on national and district level and primary data at study area, for which hypotheses were constructed and tested to quantify and draw conclusion of the study related to the impact of the basic infrastructures on the means of earnings and livelihoods of rural residents resulting poverty reduction in rural areas after the establishments of infrastructural development. The findings and conclusions of this research are as follows.

* Farmers, especially small land holders are seen benefitted by rural roads, irrigation, and fertilizers; it helped them to adopt new agricultural technologies. It seems that the new technology increased the supply of agricultural products, thus the rural peasants are benefitted from infrastructural development.

* Infrastructural development in rural areas, is like a ray of hope for better standard of living, means of earning. Education is the vital component and has is a great impact on consciousness, skill development, employment, income, business and allied activities of people, after the accessibility to educational facilities in the rural areas.

* In recent years, in Jhalari, investment in infrastructural development, access to banking, finances and co-operatives, inputs and subsidies (credit, trainings, bore pump irrigation, new agricultural vehicles and technologies, fertilizers) yielded high amount of agricultural production and reduced the lack of food shortages significantly.

Highly accessible cell phone and availability of ICT in the rural areas helped the people in the direction of occupational diversification from traditional agricultural activities to non-farm business and allied activities. Hence the means of earning and living standards of people is seen improved significantly.

It is Concluded that, there is a intricate relationship between infrastructural development and improvements in the livelihoods of the rural people. Rural areas are isolated,scarcely populated, and marginalized sectors; there are no proper basic infrastructures, so rural residents are in the situation of deprived, distressed and deteriorated condition. If there is a provision of establishment of plenty of infrastructures to the rural areas, definitely; it changes the image and fate of the rural people as well as, transform the thunder, deprived, underdeveloped areas to prosperous, potential, vibrant, smart and successful economic zones and best residential social hubs. Hence the conclusion of the study is that infrastructure development decreases the rural poverty, vis-a-vis increases the livelihoods, means of earnings and living conditions of the rural people.

\section{REFERENCES}

1. D.Carney, Approaches to Sustainable Livelihoods for Rural Poor. Overseas Development Insitute ODI, 1999

2. D.Molden, U. Amarasinghe \&I. Hussain, Water for Rural Development. International Water Management Institute IWMI,2001.

3. IFAD, Rural Poverty Report, Facts and Figures. Enabling poor rural people to overcome poverty IFAD,2011.

4. H.S.Shisodia, The Development of Rural India Through Quality and value Education (Vol. Indian Village: 2020). (Y. P. Singh, Ed.) New Delhi: Concept Publishing Company,2006.

5. K.Singh, Rural Development . New Delhi: Sage Publications,1999. 
6. K.G.Karmakar, Agricultural and Rural Development in North-Eastern India: The Role of NABARD. ASCI Journal of Management , 2008,37 (2), 89-108.

7. S.Oraboune, Infrastructure( Rural Road) Development and Poverty Alleviation in Lao PDR. Institute of Developing Economics, JETRO IDE Discussion Paper. Chiba, Japan,2008

8. B.Pramod \& N.M.Ballal, Sustainable Development of the Rural Poor. Bombay: Himalayan Publishing House, 1999.

9. F.Ellis, Rural Livelihoods and Diversifying in Developing Countries. New York: Oxford University Press, 2000.

10. M.S.Bhatia, Rural Infrastructure and Growth in Agriculture. Economic and Political Weekly, 1999,34 (13), A-43.

11. S.Fan, L.X. Zhang \& X.Zhang, Economic Change and Cultural Change ,2004, 52 (2).

12. T.H.George, Changing Scenario of Rural Labour Market. (S. B. Verma, Ed.) New Delhi: Deep and Deep Publications Pvt. Ltd,2010.

13. C.Donnges, M. Espano \& N.Palarca, Philippines Infrastrucure for Rural Productivity Enhancements, Tools for Identifying Rural Infrastructure Invsetment priorities. International Labour Organization. ASIST,AP Rural Infrastructure Publication, Bangkok,2006.

14. Z.Z.Li \& X.Liu, The Effects of Rural Infrastructure Development on Agricultural Production Technical Efficiency: Evidence from Data of Second National Agricultural Census of China. International Association of Agricultutal Economists Conference. Beijing,2009.

15. J.S.Bulus \& J.O.Adefila,The Study of Rural Infrastructure Facilities in Kajura area, Kaduna State of Nigeria. International Journal Humanities anf Social Science ,2014, 4 (2).

16. R.Gunatilaka, Rural Infrastructure Programmes for Poverty Reduction: Policy isses from the Sri-Lankan Experience. Regional Consultation on WDR201 for South Asia on " Poverty Reduction and Social Progress Bangladesh"1999.

17. S.Chandra, Our Villages: ground Realities and Future Prospects (Vol. Indian Village: 2020). (Y. P. Singh, Ed.) New Delhi: Concept Publishing Company,2006.

18. B.F.Douglas \& B.P.Hans, Impact of Rural Electrification and Infrastructure on Agricultural Changes, 1966-1980. Economics and Politcal Weekly 1986,, 21 (1), 26-34.

19. R.N.Azad Rural Development and Poverty Alleviation: Time for Reckoning (Vol. Indian Village: 2020). (Y. P. Singh, Ed.) New delhi: Concept Publishing Company,2006.

20. A.Narayanamoorthy \& M.A.Hanjra, Rural Infrastructure and Agricultural Output Linkages: A study of 256 Indian Districts. Indian Journal of Agricultural Economics 2006, 61 (3).

21. G.S.Cheema, Programme Implementation for Rural Development: An Introduction. (G. S. Cheema, Ed.) New Delhi: Sterling Publishers Private Limited,1985.

22. C.Donnges, J. Ojha \& C. Pearse, Integrated Rural Accessibility Planning in Nepal. Bangkok: ILO,2005.

23. O.P.Dev,N.P. Yadav, O. Springate-Baginski \& J. Soussan, Impacts of Community Forestry on Livelihoods in the Middle Hills of Nepal. Journal of Forest and Livelihood 2003, 1 (3), 64-77. 
24. NPC, Nepal Status Paper United Nations Conference on Sustainable Development(Rio+20). Kathmandu: National Planning Commission, GoN,2012.

25. CBS. Population Census of Nepal. Kathmandu: Central Bureau of Statistics, 2011.

26. PRB. World Population Data Sheet. New York: Population Reference Bureau, 2017.

27. UNDP. MIllennium Development Goals Report. New York: United Nations, 2010.

28. OHPI. Poverty in Rural Urban Areas : A Direct comparisons using the Global MPI. London: Oxford University, 2014.

29. Nepal Living Standard Survey. Kathmandu: Central Bureau of Statistics, National Planning Commission, 2010/11.

30. NPC. Nepal Multidimentional Poverty Index. Kathmandu: National Planning Commission, GoN/OPHI, 2018.

\section{* Corresponding Author: Ishwor Datt Awasthi}

$\mathrm{PhD}$ scholar,Tribhuvan University, Kathmandu Nepal

Date of publication on line 08.06.2018 